\title{
The Multiple Roles of Packaging in the Entire Marketing Process Channel of Distribution and Consumer Perspective
}

\author{
Patrick K. A. Ladipo (Note 1) \\ Department of Business Administration \\ University of Lagos \\ Akoka-Lagos Nigeria \\ Tel: +234-802-591-4168 \\ Thaddeus O. Olufayo (Corresponding Author) (Note 2) \\ Department of Business Administration \\ University of Lagos \\ Akoka-Lagos, Nigeria \\ Tel: +234-803-713-9013Ｅ-mail: oluthaddeusojo@yahoo.com
}

Received: August 26, 2011

doi:10.5430/ijba.v2n4p181
Accepted: October 26, $2011 \quad$ Published: November 21, 2011

URL: http://dx.doi.org/10.5430/ ijba.v2n4p181

\begin{abstract}
Packaging tends to suffer the problem of being viewed to majorly function purely as a container and hence ordained to fulfill the purpose of containerization in the entire marketing process. This article, contrary to this view, attempts to present the position that packaging functions far beyond the purpose of containerization, and has evolved in the recent past to serve the interests of the principal actors in the market-place. The principal actors include: [i] the producer; [ii] the intermediaries' and the ultimate consumers. For the middlemen, it has become an effective tool in achieving optimum use of space efficient use of shelf-space in preventing inventory losses and pilferage. For the consumers, packaging has attempted to serve their informational, promotional and convenience needs. This paper presents the multiple roles of packaging in the perspective of the middlemen and consumers.
\end{abstract}

Keywords: Product Packaging, Market Segmentation, Branding, Distribution, Middlemen, Consumer

\section{Introduction}

Packaging of product entails designing and constructing the container or wrapper for a product. The container and wrapper may take account of the product's primary container, a less important package that is disposed when the product is about to be used and the shipping package necessary to store, identify and ship the product (Kotler, Wong, Saunders \& Armstrong, 2005). Other parts of packaging include the labelling, printed information appearing on or with the package. Packaging in recent times, is seen as an important marketing strategy. Importance of packaging as a strategic tool is seen as it performs many sales tasks and it is used as competitive tool to bring competitive advantage to an organization. Also, packaging is used to attract attention, describe a product, and make sale. Firms are now realising the influence of product packaging to ensure immediate consumer recognition of a product, company or brand (Kotler et al, 2005). This paper is meant to theoretically examine multiple roles of packaging in the perspective of channels of distribution and consumers.

\section{Packaging and Channels of Distribution}

Whilst packaging, perhaps, may rightly fulfill the needs of the manufacturer (Devendorf \& Lewis, 2010), packaging aspects that relate to middlemen's handling of packaged products similarly demand attention and discussion. When packaging qualities are provided for the dealer they serve to place and keep him in a positive frame of mind about the product whilst it is in the store. One primary interest of a distributive outlet is perhaps the turnover. The dealer often relates turnover to cash return per square foot of floor space in an effort to ensure efficient space utilization.

To ensure space utilization at an efficient level, the concern of a distributive outlet is importantly sketched around the storage and display of packages as compactly as possible. The need for optimum space utilization is perhaps explained 
by high site value and the multiplicity of products, both in numbers and sizes. Because the housewife's choice of a departmental store or supermarket is to some extent influenced by the number of items carried by an outlet, the efficient use of store shelf-space (Seva, Go, Garcia \& Grindulo, 2011) becomes the more important.

Reflecting on the need for optimum utilization of space is the employment by many distributive outlets of standardized fixtures. Consequently packages with the right shapes and sizes are designed to ensure that package shape and size utilize fixtures as compactly as possible. According to Jenkins (1972) it is the wedding of the fixtures and package that leads to more sales, more profit per square foot and more convenience for the buyers.

Packages that topple from shelves may constitute another problem for the retailer; hence the retailer may develop the need to avoid such packages. This often leads to insecure stacking causing packages or cans to drop on to the floor, to be broken, dented, and trampled. Packages are now designed to prevent inventory losses from such as insecure stacking of products. According to Volckaert (1969) a shoe polish manufacturer is reported to have pleased the supermarket industry by developing a can which nests so that it can be stacked early and compactly.

Pilferage is another retail problem. Some toilet-tissue manufacturers tend to seal the wrapper ends so that small articles may not be pushed into and hidden in the round roller space. However, the retailer's receiving department may contribute to or detract from the store's profit by its efficiency at the retailer's end; packages are now designed to facilitate ease of handling, opening, marking and movement of packaged products.

Unlike a few years ago, the counter is to be found in almost every shop, and even today when we enter a shop we generally expect to see neat shelves or fixtures holding the forward stock and in front of the shelves a long and solid counter. The top of the counter is often used to display goods, and the inside may be used either for display or to hold more stocks.

In the space between the counter and the shelf is often the location for the shop assistant whose duty is to make sure that the consumer realizes her latent wants and to help her satisfy them. This represents the traditional method of selling in almost every trade. Recently, and particularly in the food trades, the traditional methods of selling have been giving way to the new idea of self-service.

With self-service, the consumer is made to do the work; she chooses, collects, and carries her own goods; the skill of the shop assistant is no longer required. Consequently products most frequently sell themselves. The more attractive and eye-appealing a package is, the faster the product is likely to sell.

For the products retailed in self-service stores or vending machines, the package becomes a vital point-of-purchase sales tool. Thus, the promotional appeal of a package is of the utmost importance to the concept of self-service. Because of the importance of the promotional appeal of a package to the distributive outlet, package colour (Devendorf \& Lewis, 2010), its shape, its trade-mark, and its type-face are appropriately, manipulated to enhance the promotional appeal and thus its capability to create optimum impression on the consumer.

\section{Packaging and the Consumer}

Packaging may be used to identify with the interests or needs of the consumers. The important needs of the consumers can be drawn to include: (i) information needs, (ii) convenience needs, and (iii) the need for packaging to protect the product to ensure safe consumption. The 'information need' is further sub-divided to include:

(a) legislated or compulsory information, and (b) promotional or voluntary product information.

Beginning in the nineteenth century many products were sold in packaged rather than on bulk form. The consumer, therefore, is no longer able to examine the product in its true generic physical form but has to rely on the information provided on the package or from the retailer in making purchase decisions. Brands and trade-marks are one means of providing the consumers with information. Because such information is apparently insufficient, several states and Federal Governments of the United States enacted legislation urging that certain information types are provided on the package. Over a period of years in the late $19^{\text {th }}$ century and the early $20^{\text {th }}$ century, specific laws require that packaged products, particularly food-stuffs, be printed with the name of the packer or distributor, the name of the item on the package, and the net weight.

It is this form of product information made mandatory by governments' legislations that is defined in this paper as legislated or compulsory product information. 


\subsection{Packaging and Legislated Product Information}

Strongly motivating the incidence of legislated or compulsory product information is perhaps the issue of consumerism or consumer revolt. According to Buskirk and Bothe (1970), the basic premise of consumerism/primarily is the result of a lack of product information for consumer's use, resulting in their incapability to buy certain goods or products.

According to Drucker (1969), “consumerism means that the consumer looks upon the producer as somebody who is interested but really does not know what the consumer realities are. He regards the manufacture as someone who has not made the effort to find out, who does not realize and understand the world in which the consumer lives, and who is the consumer to be able to make a distinction which the consumer is neither willing to make or able to make.” Thus, we see Drucker as blaming the incidence of consumerism on total negligence on the part of the producers. Buskirk and Rothe (1970) explicate the issue of consumerism as the result of the prostitution of the marketing concept, rather than a malfunction of it. According to these authors, "marketing concept and the forces labeled as consumerism are incompatible.” If consumerism exists, the marketing concept has not worked. It may be that consumerism is actually the result of prostitution of the marketing concept, rather than a malfunction of it.

It is apparent that the right to be informed, as well as the right to be heard, is of major importance. In fact, if all consumers are informed and are heard, this will then represent the fulfillment of the marketing concept. Following this declaration, the marketing sector of the economy witnesses a wave of federal laws most specifically designed to improve the consumers' positions. The table at the appendix provides a graphical illustration of a number of the legislated or compulsory product information that has been implemented.

It is instructive to suggest that the insistence on the part of the government that certain product information be compulsorily made available on packaged products may undoubtedly have been founded on the government's belief that such information will be of tremendous help to the consumers in their decision making, perhaps in relation to product quality judgment.

Since the advent of the legislated information a number of studies have been carried out to examine the effect of consumer behaviour on a number of this compulsory information. In their study of consumers' reactions to nutrition labels on food products, Lenahan et al (1973) find that only 26 per cent of their subjects see the labeling, whilst only 16 per cent understand the labeling; 9 per cent claim to have used the label at least once.

Ross (1979) works on 'unit-pricing information effectiveness' and finds that 60-70 per cent of the respondents are aware of the concept, whilst only 50 per cent understand the meaning of the concept; $30-50$ per cent claim to have used unit-price information in their buying decision; 5-38 per cent claim that some element of a shopping trip is influenced.

Day and Brandt (1973) work on 'truth-in-lending' to discover the following: 57 per cent of all credit buyers notice some credit information; 34 per cent correctly report the interest rate on a recent purchase; 54 per cent of respondents feel better knowing rates and charges; whilst only 10 per cent of all credit buyers claim to have used this information in buying durables.

Work done on open-dating by Stokes et al (1978) reveals that 65 per cent of the respondents notice the information, whilst 36 per cent know that the pull date is used. Higher degrees of satisfaction with freshness are reported. However, 39 per cent claim to have used open-dating on one or more products during their last shopping exercise or activity.

One important observation is perhaps the fact that the effectiveness of this class of product information, as reviewed above, carries no indication as to their relevance in product quality judgment. The fact, however, remains that a large proportion of this product information constitutes important product stimuli and may have significant bearings on product quality perception. This really calls for empirical validation.

\subsection{Packaging and Promotional Product Information}

One fundamental difference between legislated and promotional product information is the fact that the latter is provided voluntarily at the pleasure of the manufacturer or out of the pressure of competition. This category of information is importantly provided to influence consumer decisions in favour of the product offerings of the manufacturer providing the information.

In order to influence consumer decision-making and hence product or brand choice, packaging is in modern times, variously employed to disseminate product information to buyers. In modern marketing it has become the practice to use packaging to disseminate information concerning: (i) the content of the package, (ii) the benefits that may derive from the use of a product. The use of package copy claims represents another strategic use of packaging to disseminate product information.

The three dimensions of product information communication as outlined above will each be discussed separately. 


\subsection{Packaging as an Informant of Package Content}

One way of informing a consumer of what is contained in a package is perhaps through the product denomination. In addition to the product denomination, packaging is used in modern marketing to inform buyers of what is contained in the package.

When the package is either a tin or a box (i.e. not transparent) and the product is attractive, the common practice is to provide the package with a coloured photograph of the product as a way of saying what is contained in the package. Examples include tinned tomatoes and some pharmaceutical products such as 'Beecham Powders' and hair dyes.

Alternatively, when this is not enticing, the picture of the ingredients that go into making the product itself is provided on the package in order to inform the consumer of the content of the package.

For instance, vegetable oil is not very enticing to look at; in an attempt to give the package a strong product emphasis, the picture of the vegetable from which the oil derives is provided on the package.

Canned soups are examples of packaged products whose packaging is provided with an inviting picture of the luxurious or exotic things or materials from which they are derived. These two strategies are importantly employed to build an image for the product involved. When the product or its ingredients cannot be pictured because neither looks special, the image of the product may still be enhanced by building a suitable atmosphere around it.

For instance, rice is rather uninspiring to look at; by picturing a bowl of rice on a package, a buyer or consumer may not be influenced to choose it over another brand of rice. An atmosphere of richness may instead be created around the product and thus enhance its image by picturing on the package, a shining copper casserole containing rice, and beside it, a beautiful turkey, some silver candlesticks and other accoutrements of luxury and 'the good life'.

The technique of creating product atmosphere is very commonly used for all kinds of products. Besides its importance in the sense of informing the buyer of the package content, and in developing brand image, it is one way of planting in the mind of a consumer an association between a product and certain positive qualities that are not inherent.

Informing the consumer of the package's content is not merely confined to the use of colored photographs of the product, its ingredients or to creating product atmosphere. The package shape often tells the consumer what kind of product is inside, or at least something about its physical properties. A housewife can obviously tell whether a detergent is powdered or liquid by whether it is packed in a cardboard carton or a bottle.

A tin with a narrow-pouring spout contains liquid. Because the nature of product in containers is already stated by their shape, the graphic design is often used in giving other information about a product.

Such highly informing elements of packaging include: (i) the picture of a product or its ingredients; (ii) product atmosphere, and (iii) package shape, may perhaps be summarized into product cues, and may have a very strong implication for product quality perception.

\subsection{Packaging and Product-Benefit Information}

Just as packaging is used to disclose its content, it is similarly utilized into two ways to inform the consumer of the benefits he/she can derive from buying and consuming a product. This form of information often takes the manner of stating reasons why a product should be purchased. One way of doing this is by stating in words such reasons or benefits.

Alternatively, the argument may be presented in the form of a picture showing or depicting the benefits of having bought and consumed a product. The pictorial techniques of informing the consumer of positive benefits that may derive from using a product is evident on consumer products. Examples may be found in products such as: (i) hair spray, and body care products; (ii) toilet soaps, e.g. Lux, and (iii) SMA baby food. The package of SMA baby milk carries a beautiful coloured photograph of a healthy, plump, happy and attractive little baby, all suggestive of the benefits of feeding a baby on SMA brand of baby milk.

The pictorial technique of communicating product benefits may be viewed as a design by the marketer to fulfill the information need of the consumer. It may similarly be viewed as a cue with possible implication for product quality perception.

\subsection{Packaging and Copy Claims}

The use of package copy claims may be viewed as another design by a producer to fulfill the information needs of the consumer so as to assist her in her decision-making process. The use of copy claims is largely restricted to competitive markets such as; detergent, toothpaste, breakfast cereals and soft drinks. Copy claims which may be commonly found in 
these markets include; New!, improved!, New/Improved!, Advance Formula! and Original and Best! and a host of others.

One important observation about this class of product information is the fact that quite a number of them are ambiguous. For instance 'New!' may be interpreted to mean either of the following; improved product nutrient composition; improved performance capability; new uses; new product; new formulation; new technology and possibly new market.

In spite of the ambiguity of the concept of 'New'; marketers have long been recognized as communicating newness of their products to the consumers to re-shape their perceptions regarding their products. In fact, producers are most frequently concerned with variations of a current product rather than an entirely new one.

As Oglivy (1964), puts it “Always try and injection 'New' into your headlines because consumer is always on the lookout for new products or new ways to use an old product or new improvements in an old product. The two most powerful words you can use in a headline are free and new".

The above quotation is suggestive of the reason behind the widespread usage of the concept of 'New' and others that constitute the class of package copy claims. Similarly, concepts such as; 'Green II', Teflon II', 'TCP/2', and 'Clorex 2' is viewed as another marketing strategy at informing the consumer or the market of a second generation of these products.

Whilst the concept such as 'New' and others in the category of package copy claims are importantly intended to extend the shelf and product life of a product, such concepts may, however, be viewed by the consumer as differentiating product information and may accordingly be processed to eventuate quality judgment amongst similar products in the competitive markets.

Thus far the attempt has been to examine the various means by which packaging has been deployed to serve the information needs of the consumer. In the process two main types of information are identified: Legislated information, and promotional information.

Regarding the promotional information, three forms of product information are identified; information concerning package content; information concerning product benefits; and information via package copy claims. Pictorial diagrams, graphic design and words remain the media of information dissemination.

It must, however, be emphasized that the role of packaging in meeting the information needs of the consumer is tremendously enhanced by the higher levels of education in most industrialized societies. The higher levels of education result in increasing numbers of both consumers who have completed as many as thirteen years of formal education, and those who have, in addition, attended and/or or graduate from institutions of higher learning. The trend towards higher levels of education fundamentally causes consumers, as an overall group, to be more sophisticated when buying products, goods, and services; and are better able to handle information.

\subsection{Packaging and Consumers' Convenience Needs}

The role of packaging is not confined to meeting the information needs of the consumer; it similarly fulfills the convenience needs of the consumer in the following ways: (i) handling and storage; (ii) opening and re-closing; (iii) ease of dispensation; and (iv) preparation.

Most packaging in consumer packaged convenience products are sufficiently light to be hand-carried or handled. It is obvious that a hundred-pound sack or bag of flour is economical, but most consumers seem to find one-to-five pound boxes or bags easier to carry and store at home in their cupboards. Most packaging of detergents, ground-rice, toothpaste and salt are of such sizes that they tend to provide convenience in handling and storage.

That the dimension of a package is important as a convenience factor is evident from the concerted complaints from housewives, a few years ago, that the cereal boxes were too tall to be stored upright in standard kitchen cabinets. These packages have since been modified to fit a normal shelf.

Soft-drinks manufacturers have long been deeply concerned with convenience in packaging. For many years soft drinks were packaged in glass bottles with lift-off caps that required a can or bottle opener. In the 1950s aluminum cans appeared on the market. They were lightweight, unbreakable, and non-returnable, yet opening still required a special tool. In the 1960s self-opening cans emerged. Invention of the flip-top can make it possible for the consumer to open the can anywhere with the aid of nothing more than the human hand. Such a convenience may similarly be found on most larger cans in terms of a ring-pull device. 
Another convenience as far as the ultimate consumer is concerned, is the ease with which the package can be reclosed once opened. Bottles or jars with caps that screw back on are widespread and seem to provide such a convenience. Packaging of salts and washing-up liquids seem to provide a re-close convenience.

Excluding changes in the graphic art of packaging, most package changes in recent years have been in facilitating the product's use. All the changes to tear tapes, pouring spouts, squeeze bottles, aerosol cans facilitate ease of product dispensation.

Despite higher taxes and several bouts of inflation since 1945, it is true to say that, in the 1950-80s periods, consumers in most industrialized societies experience a substantial increase in discretionary income. In addition, higher levels of education tend to have encouraged many women and housewives to join the working population. Consequently, many consumers tend to spend relatively more on such items as prepared packaged foods which eliminate the time and effort involved in preparing untreated foods.

Such convenience may be realized from prepared package products such as frozen cauliflower, and other prepared tinned foods. Affording similar convenience include many other packaged instant food products.

\subsection{Packaging and Consumers’ Quality Needs}

The quality needs of the consumer by way of protecting the product through its journey from the factory to the ultimate consumer is particularly of tremendous concern. To uphold the quality of a product and thus prevent its degradation, the package may be important in preventing: (i) product-packaging compatibility; (ii) the ingression of liquids, vapours, gas and external odours and flavours and, (iii) contamination from micro-organisms.

Chemical interaction between a product and its container is importantly undesirable. Not only may it lead to undesirable changes in the quality of the product, it may as well cause a weakening of the container itself. Such interaction is often prevented by lacquering of the surface of the container.

One of the commonest causes of quality deterioration is water, either in the form of liquid or moisture vapour. Many granular or powdered packaged products may, for instance, cake badly under humid conditions. Quality deterioration is often prevented when moisture impermeable packaging materials are used.

It may be reasonable to suggest that devices such as package dimension, flip-top and ring-pull enhance the capability of packaging in meeting the convenience needs, together with the packaging-material enhancing the capability of packaging in fulfilling the quality needs of the consumers may constitute sufficient guides towards product quality judgment.

\section{Conclusion}

The article thus far provide a detailed account of the multiple role of packaging with regards to how the concept aptly identifies with the various needs/interests of the intermediaries and consumers, two of the three principal actors in the entire marketing process.

The interests of the intermediaries are captured to include: optimal utilization of space; prevention of inventory loss, and the promotional appeal of packaging.

The interests/needs of the consumers are captured to include: information, convenience, and protective needs.

In each case, an attempt is made to express the capability of packaging at fulfilling its multiple roles as a function of the various elements of packaging which include: colour, shape, size, material and graphic design, logo type and lettering.

Thus packaging is viewed as a bundle of stimuli created in the process of adapting same to serve the interests/needs of the producers, distributors and consumers in the market place. Some of the stimuli are believed to be used by consumers to carry out product quality judgment and choice in the market place.

Marketing practitioners are hence expected to appreciate and take relevant advantage(s) of the multiple role of packaging to advance the course of marketing management process.

\section{References}

Baker, M. J. \& McTavish, R. (1976). Product Policy and Management, Product Policy and Development, p. 34.

Bell, M., (1966). Environmental Impact on Marketing, Marketing Concept and Strategy, pp. 546-548.

Briston, J. H. \& Neil, T. H. Introduction to Packaging, Packaging Management, p. 7-9.

Britt, S. H. \& Boyd, H. W. (1973). Marketing Management and Administrative Action, McGraw-Hill Book Company, p. 401. 
Bruce, C. F., (1973). Multi-Dimensional Scaling Analysis of Grade Labelling on Consumers Perception of Product Quality, Unpublished Ph.D Thesis, Stanford University, p. 19.

Buskirk, R. H. \& Rothe, J. T. (1970). Consumerism - An Interpretation, Journal of Marketing, Vol. 34, pp. 61-65. http://dx.doi.org/10.2307/1250713

Day, G. S., \& Brandt, W. K. (2001). A Study of Consumer Credit Decisions: Implications for Present and Prospective Legislation, Washington, D. C., National Commission on Consumer Finance.

Day, G. S. (1976). Assessing the effects of information disclosure requirements Journal of Marketing, Vol. 40. p. 43. http://dx.doi.org/10.2307/1251005

Devendorf, M. \& Lewis, K. (2010). Designing a Product Package Platform, Proceedings of the ASME 2010 International Design Engineering Technical Conferences \& Computers and Information in Engineering Conference IDETC/CIE 2010 August 15 - August 18, 2010, Montréal, Quebec, Canada DETC 2010-28888

Drucker, P. (1969). Consumerism in Marketing, A Speech to the National Association of Manufacturers, New York.

Engel, J. F., Fiorillo, H. F. \& Cayley, M. A. (1972). Market Segmentation, (eds.), New York, Holt, Rinehart \& Winston, p. 10.

Howard, J. A. \& Sheth, J. N., (1969). The Theory of Buyer Behaviour, John Wiley \& Sons, New York.

Jacoby, J., Olson, J. C. \& Haddock, R. A. (1999). Price, Brand-name, and Product Composition Characteristics as Determinants of Perceived Quality, Journal of Applied Psychology, Vol. 55, No. 6, pp. 570-571. http://dx.doi.org/10.1037/h0032045

Jenkins, J. R. G. (1972). Marketing and Customer Behaviour, Pergamon Press, Oxford, N. York, Toronto, Sydney and Braunschweig, p. 8.

Kazimirski, J. (1968). Product Planning: Creating a Marketing, Geneva (Switzerland), International Labour Office.

Kennedy, J. F. (1970). Consumer Advisory Council, First Report, Executive Office of the President, Journal of Marketing, Vol. 34, p. 63.

Kotler, P. (1972). Marketing Management, $2^{\text {nd }}$ Edition, Englewood Cliffs, N.J., Prentice-Hall, pp. 182-187.

Lenahan, R. J. et al. (1973). Consumer Reactions to Nutritional Labels on food products, Journal of Consumer Affairs, Vol. 7, Spring.

Mauser, F. F. (1961). Modern Marketing Management: An Integrated Approach, McGraw-Hill, pp. 135-136.

McDaniel, C. \& Baker, R. C. (1977). Convenience Food Packaging and the Perception of Product Quality, Journal of Marketing, pp. 57-58. http://dx.doi.org/10.2307/1250234

Ogilvy, D. (1964). Confession of an Advertising Man, New York, Dell Publishing Company Inc., p. 131.

Ogilvy, D. (1979). Packaging is more that a Marketing Tool, Marketing, PIRA.

Robertson, J. S. (1967). The process of innovation and the diffusion of innovation, Journal of Marketing, Vol. 31, pp. 114-119. http://dx.doi.org/10.2307/1249295

Ross, I. (1974). Applications of Consumer Information to Public Policy Decisions, in Marketing Analysis for Societal Problems, Jaggish Sheth and Peter Wright (eds.), Urbana, III, University of Illinois.

Scwartz, D. J. (1973). Marketing Today: A Basic Approach, Harcourt Brace, pp. 349-50.

Sheth, J. N. (1967). A Review of Buyer Behaviour, Management Science, $13, \quad$ No. 12. http://dx.doi.org/10.1287/mnsc.13.12.B718

Smith, W. R., (1956). Production Differentiation and Marketing Segmentation as Alternative Marketing Strategies, Journal of Marketing, 21.

Standt, T. A., Taylor, D. A. \& Bowersox, D. J. (1976). Introduction to Marketing, Englewood Cliffs, N. J., Prentice-Hall Inc., p. 6.

Stokes, R. C. et al., (1976). Food Dating: Shoppers Relations and the Impact on Retail Foodstores Report No 984, (U.S. Department of Agriculture, Economic Research Service, Journal of Marketing.

Theodore, R. N., Packaging, Marketing Information Officer, Printing Industries, Research Association. 
Tyler, W. D. (1966). Is competitive comparison really bad in Advertising Reform with Care? Advertising Age, Vol. 37, March 14, pp. 61-62.

Volckaert, M., (1969). Packaging Design Facing up to the Market, International Trade Forum, p. 21.

Volckaert, M. (2002). Packaging Facing up to the Market, International Trade of Forum, pp. 14-15.

\section{Notes}

Note 1. Dr. Patrick K. A. Ladipo holds a B.Sc. in Agric Economics, M.Sc. in Marketing and Ph.D. in Marketing. He is a lecturer 1 in the Department of Business Administration, University of Lagos, Akoka.

Note 2. Thaddeus O. Olufayo holds a B.Sc. in Business Administration, M.Sc. in Marketing and currently a Ph.D. (Marketing) student in the Department of Business Administration, University of Lagos, Akoka.

Table 1. Information disclosure requirements: illustrative, not comprehensive

\begin{tabular}{|l|l|l|}
\hline & Types of Disclosure & Implemented in the past 30 years \\
\hline 1 & Comparative Prices & $\begin{array}{l}\text { Truth in lending } \\
\text { Unit pricing } \\
\text { Automobile list prices }\end{array}$ \\
\hline 2 & $\begin{array}{l}\text { Comparative } \\
\text { performance and ability }\end{array}$ & $\begin{array}{l}\text { Nutrition labeling of food products } \\
\text { Lumern and life data for light bulbs } \\
\text { Stereo amplifier power output } \\
\text { Octane labeling } \\
\text { Automobile performance (vehicle stopping distance, } \\
\text { acceleration and passing ability, and tyre reserve load) }\end{array}$ \\
\hline 3 & $\begin{array}{l}\text { Ingredients (including } \\
\text { additives) }\end{array}$ & $\begin{array}{l}\text { Cosmetics } \\
\text { Food } \\
\text { Liquor } \\
\text { Phosphate content of detergents }\end{array}$ \\
\hline 4 & Life/Perishability & Open dating of foods \\
\hline 5 & Warnings/Clarifications & $\begin{array}{l}\text { Cigarette health hazards } \\
\text { Lack of efficacy of vitamins } \\
\text { Flammability (children's sleep wear) }\end{array}$ \\
\hline 6 & $\begin{array}{l}\text { Form and usage of } \\
\text { product/terms of } \\
\text { contract and warranties }\end{array}$ & $\begin{array}{l}\text { Size standards (i.e. TV screens and refrigerators) } \\
\text { Truth in warranties and service contracts } \\
\text { Tyre construction and load rating }\end{array}$ \\
\hline
\end{tabular}

Source: Journal of Marketing, Vol. 40, April 1976 